DOI: 10.19085/journal.sijbpg030501

\title{
The Convergence of U.S. GAAP with IFRS: A Comparative Analysis of Principles- based and Rules-based Accounting Standards
}

\author{
Dr. Oris Guillaume (MA, JD, DBA) \\ Post-Doctoral in Accountancy, Professor of Management, Chair Graduate Business Programs \\ Shorter University, USA. \\ Dr. Denel Pierre (DBA, MBA) \\ Adjunct Professor of Finance and Accounting, Argosy University, USA.
}

(c) Scholedge International Journal of Business Policy \& Governance (ISSN 2394-3351), Vol.03, Issue 05 (2016) pg63-72. Published by: Scholedge R\&D Center [www.theSCHOLEDGE.org] [Email: editorial@thescholedge.org]

\begin{abstract}
The Financial Accounting Standard Board (FASB) and the International Accounting Standard Board (IASB) have been working jointly toward the convergence of the U.S. generally accepted accounting principles (GAAP) and the international financial reporting standards (IFRS). However, several arguments still exist as to whether or not U.S. companies should adopt or converge with IFRS. This qualitative study identified the differences noted between rules-based and principles-based accounting, and discussed the impact of these accounting standards on financial reporting. Additionally, several resources were analyzed to understand the path to convergence and the future state of IFRS. The examination of information regarding the transition towards one single set of accounting standards led to the development of two alternate conclusions. Although research allows for the belief that convergence with IFRS is imminent, the fact remains that FASB and IASB will need to work diligently in order to resolve the differences between the two sets of accounting standards.
\end{abstract}

Keywords: GAAP, IFRS, FASB, IASB, Adoption, Convergence, Rules-based, Principles-based, Accounting Standards, Financial Reporting

\section{Introduction}

According to Miller and Becker (2010), "Countries have long had their own version of GAAP, because; GAAP development is influenced by local culture, educational systems, religious beliefs, and other country-specific factors" (p. 64). Research also indicated that although International Financial Reporting Standards (IFRS) are used as the method of financial reporting by over 15,000 companies outside of the United States, the debate over whether the public companies based within the United States should adopt or converge with IFRS remains. Callaghan and Treacy (2007) agreed that significant strides have been made towards understanding the differences between U.S. GAAP and IFRS but, there seems to be hesitation within U.S. public companies to migrate towards fully adopting a principles-based method of accounting. The researchers will use an exploratory qualitative research method that compares rules-based and principles-based accounting standards. 


\section{Purpose of the Study}

The purpose of this qualitative study is to explore the literature which covers the rules-based and principles-based accounting standards. Through analysis of these standards, the researchers will determine the future of U.S. GAAP convergence with IFRS. Notably, it has not been determined that one method of reporting is superior to other, however, the reporting standards and inconsistencies between U.S. GAAP and IFRS have impacted adoption of one standard method of accounting. Both accounting boards are working together develop a feasible and consistent method for reporting transactions on the financial statements. In the meantime, issues identified between U.S. GAAP and IFRS accounting methods have been addressed, so that convergence could happen by 2015 . Nevertheless, while we are in mid-2016, the convergence is yet to happen.

\section{Problem Statement}

According to Spiceland, Sepe, and Nelson (2013), the accounting scandals at Enron, WorldCom, and other corporations ignited the debate over principles-based versus rules-based accounting standards. The Sarbanes-Oxley Act of 2002 (SOX) required the Securities and Exchange Commission (SEC) to conduct a study on the issue and report the findings to Congress. On July 2003 , the SEC published the report and recommended the use of a principles-based approach to develop accounting standards. The FASB agreed with the SEC to develop principles-based standards (Spiceland et al., 2013). Proponents of principles-based accounting standards argue that it focuses more on professional judgment, there are fewer rules to bypass, and it will more likely lead to an appropriate accounting treatment. However, opponents of the principles-based approach argue that the lack of detailed rules will even lead to more abuse (Spiceland et al., 2013). While the debate for consistent reporting standards between U.S. GAAP and IFRS continues, U.S. companies remain hesitant to migrate towards fully adopting principles-based method of accounting.

\section{Background of the Study}

Recent scandals regarding unethical and immoral behavior in business have plagued the media, and it has become overwhelmingly obvious that there is a need for companies to focus on the reporting of financial information. While the basic purpose of an entity is to maximize profit and shareholder's wealth (Beauchamp \& Bowie, 2004), the integrity of financial reporting and consistency between reporting standards for U.S. public companies is essential. Thus, understanding the accounting methods used both domestically and abroad is vital to ensuring that the proper reporting standards are being followed. Callaghan and Treacy (2007) agreed that significant strides have been made towards understanding the difference between U.S. GAAP and IFRS, but there seems to be reluctance within U.S. public companies to fully adopt a principles-based method of accounting.

Research indicated that IFRS are used as the method of financial reporting for over 15,000 companies outside of the United States. Spiceland et al. (2013) believed that more and more countries are adopting the IFRS. The American Institute of Certified Public Accountants (AICPA) indicated that currently, 120 nations and reporting jurisdictions permit or require IFRS for companies listed domestically, whereas 90 countries have fully adopted IFRS. The debate over whether public companies based within the United States should adopt or converge with IFRS remains. Although the SEC's roadmap projected for U.S. companies to present financial statements under IFRS in 2014, SEC Chairman, Mary Schapiro stated, "The first time U.S. companies could be required to report under IFRS would be no longer than 2015" (Spiceland et al., 2013 p.13). While we are in mid-2016, we are still waiting for the convergence to happen. 
This paper explores the literature that covers the background and current status of U.S. GAAP and IFRS and determines the future of IFRS. Notably, it has NOT been determined that one method of reporting is superior to the other, however, the reporting standards and inconsistencies between U.S. GAAP and IFRS have impacted adoption of one standard method of accounting. In fact, in November 2011, the SEC published two studies where it compared the U.S. GAAP and IFRS and how IFRS is applied globally. In these studies, the agency identified the key differences between the two sets of standards and suggested that the U.S. GAAP provided significantly more guidance about particular transactions and industries (Spiceland et al., 2013). The SEC also believed that IFRS presented some potential for non-compatibility of financial statements across countries and industries; however, both accounting boards are working together develop a feasible and consistent method for reporting transactions on the financial statements.

\section{Timeline for IFRS Acceptance in the United States}

\begin{tabular}{|c|c|}
\hline $\begin{array}{l}\text { 01: The International Accounting Standards Board } \\
\text { ASB) is established as the successor organization to the } \\
\text { ternational Accounting Standards Committee (IASC), } \\
\text { rmed in 1973. The IASB's mandate is to develop } \\
\text { ternational Financial Reporting Standards (IFRS). }\end{array}$ & $\begin{array}{l}\text { updated Memorandum of Understanding } \\
\text { that focuses the energies of both boards } \\
\text { toward convergence of important } \\
\text { accounting standards, such as revenue } \\
\text { recognition, leases and consolidation. }\end{array}$ \\
\hline $\begin{array}{l}\text { 002: The IASB and the Financial Accounting Standards } \\
\text { oard (FASB) issue the Norwalk Agreement, } \\
\text { cknowledging the joint commitment to developing high- } \\
\text { uality, compatible accounting standards that could be } \\
\text { sed for both domestic and cross-border financial } \\
\text { eporting. Also, the European Union (EU) announces that } \\
\text { s member states will require IFRS in the preparation of } \\
\text { onsolidated financial statements of listed companies } \\
\text { eginning in } 2005 \text {. }\end{array}$ & $\begin{array}{l}\text { 2009: The IASB ended its moratorium, set } \\
\text { in 2005, on the required application of } \\
\text { new accounting standards and major } \\
\text { amendments to existing standards. The } \\
\text { board had frozen its rules while more } \\
\text { countries adopted IFRS. Japan introduces } \\
\text { a roadmap that could lead to a decision in } \\
2012 \text { to adopt IFRS, with proposed } \\
\text { adoption dates in } 2015 \text { or } 2016 \text {. }\end{array}$ \\
\hline $\begin{array}{l}\text { Intant of the Securities and Exchange } \\
\text { releases a roadmap allowing IFRS } \\
\text { GAAP reconciliation for foreign firms }\end{array}$ & $\begin{array}{l}\text { 2010: The SEC releases a staff Work Plan } \\
\text { to evaluate the effect that using IFRS } \\
\text { would have on the U.S. financial } \\
\text { reporting system. The SEC notes that } \\
2015 \text { is currently the most likely first } \\
\text { adoption year. Japan allows certain } \\
\text { qualifying domestic companies the } \\
\text { option to use IFRS for fiscal years ending } \\
\text { on or after March 31, 2010. }\end{array}$ \\
\hline $\begin{array}{l}\text { 2006: The IASB and the FASB agree to work on a number } \\
\text { of major projects. } \\
\text { 2007: The SEC announces that it will accept from foreign } \\
\text { filers in the U.S. financial statements prepared in } \\
\text { accordance with IFRS, as issued by the IASB, without } \\
\text { reconciliation to U.S. GAAP. Also, the SEC issues a Concept } \\
\text { Release asking if U.S. public companies should be given an } \\
\text { option to follow IFRS instead of } \\
\text { U.S. GAAP. }\end{array}$ & $\begin{array}{l}\text { 2011: Canadian and Indian companies } \\
\text { begin using the global standards, and } \\
\text { Japan is slated to have eliminated all } \\
\text { major differences between Japanese } \\
\text { GAAP and IFRS. SEC to evaluate feasibility } \\
\text { of requiring use of IFRS based on } \\
\text { completion of the outstanding } \\
\text { MoU items and on results of the } 2010 \\
\text { staff Work Plan. In the United States, } \\
\text { questions concerning IFRS are included in } \\
\text { the Uniform CPA Exam. }\end{array}$ \\
\hline & $\begin{array}{l}\text { 2012: Mexic } \\
\text { all listed en }\end{array}$ \\
\hline
\end{tabular}


toward acceptance of IFRS. The roadmap also would allow early adoption of IFRS for U.S. public companies that meet certain criteria. The AICPA's governing Council votes to recognize the IASB as an international accounting standard setter under rules 202 and 203 of the Code of Professional Conduct, thereby giving U.S. private companies and not-for-profit organizations the choice to follow IFRS.

Adopted from: American Institute of Certified Public Accountants (IACPA). Retrieved from http://www.ifrs.com/pdf/IFRSUpdate_V8.pdf.

\section{Current Status of IFRS - Identified Reporting Differences}

Discrepancies between methods of accounting for U.S. GAAP and IFRS have been noted; these differences have created concerns over consistency with financial reporting. The basis for the differences in accounting methods stems from the fact that U.S. GAAP uses rules-based standards while IFRS uses principles-based standards. Rules-based standards are used by FASB and provide solutions for all or most application issues. U.S. GAAP rules are seen as a "prescription-based" approach which provides specific details directing how "implementation is to be effected" (Needles \& Powers, 2010; Epstein, Nach, \& Bragg, 2008, p. 1236). Conversely, principles-based standards are noted as being a set of guidelines, allowing for greater latitude of interpretation by the preparer or auditor (Epstein, Nach, \& Bragg, 2008). However, opponents of principles-based accounting standards argue that reliance on professional judgment may result in different interpretations for similar transactions, raising concerns about comparability of financial statements (Spiceland et al., 2013).

\section{Theoretical Framework}

Research indicated that Principles-based and rules-based standards differ from each other in the some ways. Conceptually, rules-based standards are less reliant upon professional judgment, whereas principles-based standards are more reliant upon professional judgment. More level of detailed guidance is provided for rules-based standards, but less detail is provided for principles-based standards (allowing for greater latitude to use professional judgment). Sacho and Oberholster (2008) defined a principles-based accounting approach as one that is dependent on the prudence of accounting and/or financial professionals in the application of accounting criterion to varying positions. Lindberg and Siefert (2010) argued that IFRS requires the interdependency on sound judgment and not on the fine-points or the particulars of rules.

Lastly, there is an extensive amount of industry specific guidance for rules-based standards, but little guidance is provided for the principles-based approach (Needles \& Powers, 2010).

The SEC was directed by Sarbanes-Oxley to investigate whether one standard was superior to the other, and the SEC concluded in part that, "... both rules and principles are necessary and endorsed a comprehensive compromise position” (Epstein, ch, \& Bragg, 2008, p. 1236). Nevertheless, the distinction between rules-based (U.S. GAAP) versus principles-based (IFRS) accounting methods and the execution of these standards impact several areas in methods of accounting, particularly revenue recognition, asset valuation and inventory accounting, and classification of debt and equity. These differences ultimately affect financial statement reporting

\section{Methodology}

This study used a qualitative approach to explain the convergence of U.S. GAAP with IFRS. Furthermore, after we conduct a comparative analysis of principles-based to rules-based accounting Standards, we have discovered that the SEC was directed by Sarbanes-Oxley to investigate whether 
one standard was superior to the other, and the SEC concluded in part that, "... both rules and principles are necessary and endorsed a comprehensive compromise position" (Epstein, ch, \& Bragg, 2008, p. 1236). Nevertheless, the distinction between rules-based (U.S. GAAP) versus principles-based (IFRS) accounting methods and the execution of these standards impact several areas in methods of accounting, particularly revenue recognition, asset valuation and inventory accounting, and classification of debt and equity. These differences ultimately affect financial statement reporting. The following questions have grounded the quality study:

What is the difference between GAAP and IFRS?

What is the difference between convergence and adoption?

What could be the disadvantages of converting to IFRS?

These key questions have helped us to analyze and synthesize the key difference GAAP and IFRS. Adoption would mean that the SEC sets a specific timetable when publicly listed companies would be required to use IFRS as issued by the IASB. Convergence means that the U.S. Financial Accounting Standards Board (FASB) and the IASB would continue working together to develop high quality, compatible accounting standards over time. These differences lead to wide variations when IFRS are computed under US GAAP and it is found that Profits computed under US GAAP are generally lower Some of these major differences between US GAAP

\section{Revenue Recognition}

Among the issues noted between U.S. GAAP and IFRS, revenue recognition highlights a major contrast in approaches to accounting. While U.S. GAAP uses rules-based accounting and is driven by more industry specific guidance when determining when and how much revenue should be recognized, IFRS's principles-based accounting method relies more on judgment (providing less guidance when it comes to industry specific transactions).

Needles and Powers (2010) explained that U.S. GAAP and IFRS approach of accrual accounting in two very different ways. For example, U.S. GAAP uses the 'matching rule and measurement of items' on the income statement. Thus, revenue is recognized in the period in which it is earned and expenses are recorded in the period incurred; however, "IFRS emphasizes measurement of assets and liabilities on the balance sheet at fair value" (Needles and Powers, 210, p. 35). Consequently, increases and decreases of revenues and expenses are reflected on the income statement.

It stands to reason that this significant difference as to when and how much income should be recognized will ultimately impact financial statements. Analysis by PricewaterhouseCoopers (2008) agrees with this line of thinking and noted that the differences in revenue recognition will have a significant impact on U.S. businesses.

\section{Inventory Valuation}

Inventory is defined as, "Assets that a company intends to sell in the normal course of business, or is in production for future sale or used currently in production of goods to be sold" (Jeffers \& Askew, 2010, p. 45). One of the two main differences noted between U.S. GAAP and IFRS inventory accounting is that U.S. GAAP allows for use of the last-in-first-out (LIFO) accounting method for cost inventory, whereas while LIFO is prohibited by IFRS (Needles \& Powers, 2010). Literature indicates that the effect of not using LIFO (for U.S. companies that currently do) will be noted in tax reporting and on the financial statements (balance sheet and income statement) (Hughen, Livingstone, \& Upton, 2011). Bloom and Cenker (2009) also noted in part that, “... IFRS requires entities to carry inventory at the lower of cost or net realizable value; GAAP values inventories at current replacement cost, which has a ceiling of net realizable value and a floor of net realizable value minus a normal profit margin" (p. 44). 
One of the major concerns is the tax implication that is associated with the differences in methods of accounting for inventory by the two reporting standards. Additionally, the effect of the change in inventory valuation will have an impact on both the balance sheet and income statement; tax burdens will also be realized more extensively for certain industries (e.g., the oil industry). This notwithstanding, some corporations are actually voluntarily discontinuing the use of LIFO as a method of inventory valuation (Hughen, Livingstone, \& Upton, 2011).

\section{Financial Statement Consolidation}

Consolidation of financial statements is another area that demonstrates the differences between U.S. GAAP and IFRS accounting methods. Consolidated financial statements are defined as "statements presenting, primarily for the benefit of the shareholders and creditors of the parent company, the results of operations and the financial position of a parent company and its subsidiaries essentially as if the group were a single enterprise with one or more branches or divisions (Epstein, Nach, \& Bragg, 2008, p. 558). U.S. GAAP relies on a percentage of ownership to determine whether or not financial statements need to be consolidated. Conversely, IFRS places more emphasis on "judgment rather than voting control" (Needles \& Powers, 2010, p. 44). The fact that IFRS relies on judgment is not surprising; because IFRS does not have industry specific guidance and is more principles-based (rather than rules-based), it is obvious that judgment would be a key factor in determining when financial statement should be consolidated.

The inconsistency between U.S. GAAP and IFRS in the approach of consolidation remains as an outstanding issue (Heffers, 2009). If the approach to consolidation (along with other differences noted between U.S. GAAP and IFRS) is not resolved, unwanted financial reporting issues are likely to be uncovered in the future.

\section{Impact on Financial Reporting}

\section{Financial Statement - Proposals}

Several changes have been proposed regarding how IFRS (which differ from U.S. GAAP) will identify the financial statements. As noted by Needles and Powers (2010) the proposed new name for the income statement is "Comprehensive Income". This new name includes the word comprehensive because the statement will include items that previously were disclosed separately as comprehensive income. Additionally, what is currently called the "Balance Sheet" by U.S. GAAP is proposed to be titled "Statement of Financial Position" and the Statement of Stockholders' Equity will be titled "Statement of Change in Equity" by IFRS (p. 20). While the proposed name changes do not seemingly present concerns, the change in terminology should be understood by investors, stakeholders, and stockholders when trying to determine the financial position of the company.

\section{Financial Statement - Presentation}

The balance sheet under proposed IFRS differs from U.S. GAAP in the following ways: IFRS uses the title "Statement of Financial Position" instead of the title "Balance Sheet" used by U.S. GAAP; IFRS do not mandate the format of the statement of financial position. This means that while some entities may choose Assets-Liabilities=Equity, other entity may choose Assets =Liabilities + Equity or Fixed assets + Current assets - Short-term payables = Long-term debt + Equity. Unlike U.S. GAAP, IFRS specifically prohibits "deferred tax assets/liabilities" in current assets and liabilities. In addition, IFRS requires a comparison of current and prior year statements, U.S. GAAP does not specify this requirement. Lastly, U.S. GAAP specifies the order of assets must follow (current assets ahead of noncurrent assets); IFRS does not (Needles \& Powers, 2010).

Additional classification differences were noted between U.S. GAAP and IFRS (i.e., assets, liabilities, debt and equity). While U.S. GAAP allows for items that are neither debt nor equity to be categorized in a "mezzanine" category (Needles \& Powers, 2010), literature indicated that IFRS does 
not have a 'neither debt nor equity' category. All items are either classified as being debt or equity. Gray, Linthicum, and Street (2009) noted that the differences in U.S. GAAP and IFRS debt and equity classification is an issue that must be addressed before convergence can be accomplished.

\section{Further Reporting Differences}

The previous section explored the facts surrounding (some, but not all of) the current issues noted with U.S. GAAP and IFRS methods of accounting. Notably, other concerns with different methods of accounting are the handling of costs for the following: plant, property and equipment (PP\&E), research and development $(R \& D)$, impairment, future purchase commitments, and sharebased payments.

In fact, the valuation of PP\&E is handled differently by IFRS; historical costs or fair value is used to determine the value of PP\&E. Future purchase commitments are recognized by IFRS if the following criteria are met: there are probable future economic benefits; revenue and costs can be measured reliably; significant risk and rewards of ownership are transferred; managerial involvement is not retained as to ownership or control (Needles \& Powers, 2010).

Whereas the FASB and IASB are working to resolve the issues noted, it is important to understand what lies ahead for companies (and their leaders) as the path towards convergence continues.

The major difference between how U.S. GAAP and IFRS handle Share-Based Payments (SBP) is that, "U.S. GAAP rules apply only to employee SBP; IFRS apply to all SBP, including non-employee SBP" (Needles \& Powers, 2010, p. 44). We should also be noted that U.S. GAAP and IFRS have made adjustments in the way SBP are classified. The determination of whether SPB are classified as liabilities depends upon how the payments are settled or if the shares are 'puttable' (KPMG, 2008, p. 5). In additionally, Ernst \& Young (2015) explained that deferred taxes for SBP are handled differently by IFRS and U.S. GAAP. Under IFRS 2, deferred tax assets are measured according to the expected amount, re-measured according to the share price (intrinsic value), but " if intrinsic value at settlement is less than grant-date fair value, cumulative tax benefit recognized is based on intrinsic value". Interestingly, research indicated according to FAS $123 \mathrm{R}$, the intrinsic value method for measuring the cost of all SBP plans has been eliminated, and "... where equity instruments are issued to employees, the fair value model is used to measure the compensation cost" (Epstein, Nach, \& Bragg, 2008, pp. 936-937).

\section{Convergence - Impact and Future of IFRS}

According to Lugo (2010), the main purpose of convergence is to develop a single set of distinctive standards that could be used globally. Lugo also argued that by stating that a single set of financial reporting standards would provide consistent control for all entities involved. The idea that the issue of convergence merely affects those who deal with accounting (i.e., accountants, auditors, and the like) is inaccurate. Leaders within organizations are going to need to be equally aware of the impact of convergence and understand the financial changes that will be evidenced through the company's bottom line. Companies are slowly migrating and learning the different terminology used in each of the financial statements. Leaders will be required to explain these changes to investors and stakeholders. Cereola, Louwers, and Wheeler (2011) indicated that through the Management Discussion and Analysis (MD\&A), management is required to disclose information describing the financial standing and exceptions noted on the financial statements, so that investors can determine whether past performance will be indicative of future performance.

Research explained that it seems reasonable to require U.S. public companies to incorporate IFRS; however, arguments can be made to persuade the thinking that the future of IFRS remains dismal. Although Busman and Landsman (2010) noted in part that, "... competition rather than convergence in accounting standards will persist" (p. 263). FASB and IASB have continued relentlessly 
in the pursuit to arrive at one single set of accounting standards. Ultimately, the goal of both accounting boards is to use a method of accounting that will allow for consistency in financial reporting.

Literature suggests that there are pros and cons for regulating reporting standards for U.S. public companies. Bushman and Landsman (2010) suggested that a one-size fits all approach is not necessarily the best approach to ensuring consistency in financial reporting. Furthermore, it was noted that the political climate (i.e., political views, development, regime, corruption, and the like) within foreign countries should be factored into the decision to standardize accounting methods.

Reviews and analyses of literature support the assertion that alternate conclusions can be drawn when determining the future of IFRS. Research indicates that there are differing opinions as to what alternative should be addressed as organizations pursue in their quest to either adopt or converge with IFRS. Studies showed that the idea of convergence, rather than adoption, appears to be most feasible since there are still so many fundamental issues regarding differences between U.S. GAAP and IFRS accounting methods. According to Spiceland, Sepe, and Nelson (2013), many people argue that a single set of global standards will improve compatibility of financial reporting and facilitate access to capital, but U.S. standards should remain customized to fit the stringent legal and regulatory requirements of the U.S. business environment.

\section{Future Research}

Truly understanding the ramifications for U.S. public companies to converge with IFRS is a tremendous undertaking. More importantly, understanding what type of education regarding U.S. GAAP and IFRS is a more pertinent question. What research seemingly has not addressed is the cost associated with changing the current curriculum provided in undergraduate and graduate accounting programs. Specifically, typical curriculum for undergraduate accounting programs focus on financial, managerial, intermediate, fraud, and tax accounting. Although textbook publishers begin to incorporate some components of IRFS, what cost would be associated with adding additional courses that focus more on principles-based accounting standards and IFRS? What IFRS related changes would be made to the CPA exam, and what classes would be available to prepare accountants to successfully complete the exam? What continuing professional education would be provided to educators to meet students' needs? Miller and Becker (2010) noted that, "Accounting educators should be able to teach IFRS the same way they now teach GAAP; accounting programs will need to make massive changes in the next several years if the United States transitions from GAAP to IFRS" ( $p$. 63).

\section{Conclusions}

Because the SEC recommended the use of a principles-based approach to develop accounting standards, companies using U.S. GAAP will have to consider converging with IFRS accounting methods. While the differences in reporting are evident, PricewaterhouseCoopers (2007) indicated that the key issue for companies is consistency in reporting. Corporate leaders and managers need to understand what convergence truly means, and investors and shareholders need to be confident that the financial statements provided are consistent and reliable. As such, companies should require training for organizational leaders to aid in the education of IFRS principles-based methods. Additionally, this training should also be provided for other organizational members and investors. This would aid with understanding the reporting differences noted between domestic and foreign entity financial statements.

Although this alternative seemingly is reasonable, some things should be kept in mind. For example, companies would need to understand the cost involved with providing training for leaders 
(such as accountants and CFOs) within the organization. As noted by Schipper (2010), cost/benefit analysis is a vital part of understanding the impact of convergence with IFRS and changes in financial reporting standards. As a precaution [however] literature explained that convergence with IFRS is likely to be approached by management as a 'project'; as such cost/benefit analysis can be a difficult task if the time period involved for the project is ongoing (Schipper, 2010).

Surveys collected from CPAs in public practice regarding IFRS in the United States indicates that because of the enormous amount of changes made within both U.S. GAAP and IFRS accounting methods, companies and large accounting firms have compiled multiple resource materials to provide to "their constituents, as well as colleges and universities" (Langmead \& Soroosh, 2010, p. 30).

Although a decision to adopt IFRS has not been definitively determined, there are differing opinions about convergence to IFRS. While some feel that the topic of convergence will remain unresolved, others are optimistic about the idea of having one set of global accounting standards. Many argue that a single set of high-quality accounting standards will improve comparability, transparency, verifiability, value relevant, and understandability of financial information. They believe that the convergence will bring many challenges for corporations, investors, and accounting professionals, but it will present many opportunities for them. Jeffers and Askew (2010) noted that FASB and IASB have been diligently working to achieve the goal of adopting one set of accounting standards; by 2016 it is likely that transition from GAAP to IFRS for large multinational companies will not occur.

\section{References}

AICPA. (2011). Timeline for IFRS Acceptance in the United States. Retrieved from http://www.ifrs.com/Backgrounder_GAAP_IFRS.html.

AICPA. (2013). How widespread is the adoption of IFRS around the world? Retrieved from http://www.ifrs.com/ifrs_faqs.html.

Beauchamp, T. L., \& Bowie, N. E. (2004). Ethical theory and business (7 ed.). Upper Saddle River, NJ: Prentice Hall.

Bloom, R., \& Cenker, W.J. (2009). The death of LIFO? Journal of Accountancy, 207(1), p. 44-49.

Bushman, R., \& Landsman, W.R. (2010). The pros and cons of regulating corporate reporting: a critical review of the arguments. Accounting and Business Research, 40(3), 259-273. Retrieved from http://search.proquest.com/docview/726392774?accountid=13843

Callaghan, S. \& Treacy, M. (2007). Towards convergence: IFRS to US GAAP differences. Accountancy Ireland, 39 (6).

Cereola, S.J., Louwers, T.J., \& Wheeler, S.W. (2001). Who's watching the MD\&A? Internal Auditing, 26(2), 21-26.

Epstein, B.J., Nach, R., \& Bragg, S.M. (2008). Wiley GAPP: Interpretation and application of Generally Accepted Accounting Principles. John Wiley \& Sons: Hoboken, NJ.

Ernst \& Young. ( 2015). Accounting for Share-based Payments under IFRS 2 - The essential Guide. Retrieved

from: http://www.ey.com/Publication/vwLUAssets/Applying_IFRS:_Accounting_for_sharebased_payments_under_IFRS_2_-_the_essential_guide./\$File/Applying-SBP-April2015.pdf.

Gray, S.J., Linthicum, C.L., \& Street, D.L. (2009). Have European and US GAAP measures of income and equity converged under IFRS? Evidence from European companies listed in the US. Accounting and Business Research, 39(5), p. 431-447.

Heffers, E.M. (2009). Toward global standards on consolidation and recognition. Financial Executive, 25(7), 14-15.

Hughen, L., Livingstone, J.R., \& Upton, D. (2011). Switching from LIFO: Strategies for change. The CPA Journal, 26-29.

Jeffers, A.E., \& Askew, S. (2010). Analyzing financial statements under IFRS: Opportunities \& challenges. Journal of Leadership, Accountability, and Ethics, 8(1), 45-57.

Lindberg, D. L., \& Seifert, D.L. (2010). A new paradigm of reporting on the horizon: 
International financial reporting standards (IFRS) and implications for the

insurance industry. Journal of Insurance Regulation, 29, 229-252.

Lugo, D. (2010). FCAG urges G-20 to participate, endorse final IASB, FASB standards on convergence. Accounting Policy \& Practice Report, 6(1), 26-27.

Miller, W.F., \& Becker, D.A. (2010). Why are accounting professors hesitant to implement IFRS? The CPA Journal 80(8), 63-67. Retrieved from http://search.proquest.com/accounting /docprintview/749930306/132354BC98D73161FBE/

Needles, Jr., B.E. \& Powers, M. (2010). International financial reporting standards: An introduction (2nd ed.). Mason, $\mathrm{OH}$ : Southwestern Publishing.

PricewaterhouseCoopers (2007). Presentation of income under IFRS: Flexibility and consistency explored. Retrieved from www.pwc.com/ifrs.

Sacho, Z. Y. \& Oberholster, J. G. I. (2008). Factors impacting on the future of the IASB. Meditari Accountancy Research, 16(1), 117-137.

Schipper, K. (2010). How can we measure the costs and benefits of changes in financial reporting standards? Accounting and Business Research, 40(3), 309-327. Retrieved from http://search.proquest.com/docview/726391189?accountid=13843

Shortridge, R.T., \& Myring, M. (2004). Defining principles-based accounting standards. The CPA Online Journal. Retrieved from http://www.nysscpa.org/cpajournal/2004/804/essentials/p34.htm.

Spiceland, J. D., Sepe, J. F., \& Nelson, M.W. (2013). Intermediate Accounting ( $7^{\text {th }}$ ed.). New York, NY: McGraw-Hill Companies, Inc. 